\title{
A SERVQUAL ASSESSMENT OF INTERNET SERVICE QUALITY IN BHUTAN
}

\author{
${ }^{1}$ Phurba Sonam Waiba, ${ }^{2}$ Aita Raj Limboo ${ }^{2}$ Jigme Sherub. \\ ${ }^{1}$ Ministry of Labour and Human Resources, \\ ${ }^{2}$ Ministry of Education, Royal Government of Bhutan
}

\begin{abstract}
Internet and telecommunication is nowadays one of the core necessities and is in fact required in every aspect of our daily lives. Bhutan introduced the internet and television in 1999. Internet and telecommunication has taken its roots in Bhutan and in every nook and cranny of the country. Given its importance, it is important to time to time assess its quality in the country for learning and development purposes.
\end{abstract}

The study is based on quantitative analysis, using the SERVQUAL instrument. The data was collected through randomly distributed questionnaires through convenience sampling method via google form survey. Sample size of $\mathbf{3 8 4}$ was determined using an online survey monkey tool.

The data for this study was analyzed using excel through paired two sample t-test to compare means and to see the significant difference between expectation and perception of the services of each dimension item of all the five dimensions at hypothesized mean difference of zero, alpha value of 0.05 . The average gap score is at $\mathbf{- 0 . 6}$ which means that the expectations have not been met and quality of internet service is unsatisfactory. Interesting to note that TANGIBILITY, EMPATHY and RELIABILITY aspects require immediate attention. Generally, the difference between the two means is statistically significant, and therefore there is a statistical significant difference between perceived and expected internet service quality.

The study therefore, recommends the (internet service providers) ISPs to consider improvements and rethinking developments on the dimensions discussed in the paper.

Keywords—internet, service quality \& SERVQUAL.

\section{INTRODUCTION}

Information and telecommunication has been accorded high priority in Bhutan's development plans since 1965 (MoIC, 2014). The country saw its first telephone network in 1963 and its first television and internet services in 1999 and later cellular phone in 2003 (MoIC, 2014). Druknet was the only Internet Service Provider (ISP) in Bhutan in the past. Druknet was launched on June $2^{\text {nd }}$, 1999 during the Silver Jubilee Celebration of the coronation of His Majesty the fourth Druk Gyalpo Jigme Singye Wangchuck with the financial and technical assistance of International Development Research Centre (IDRC) and the United Nations Development Programme (UNDP). Bhutan was one of the last countries in the world to have no Internet until 1999 but this development is hailed as a landmark and historic event in the country. Druknet was under Bhutan Telecom and was located in Thimphu (Pradhan, 2001). Today, Bhutan has a digital telecommunication network reaching far and wide across the nation. Besides reaching all district headquarters, telecom services are also available in every remote location.

Bhutan Telecom is the state owned leading provider of cellular and internet services which was launched on $1^{\text {st }}$ July 2000 (MoIC, 2014). With the entry of the privatelyowned Tashi InfoComm (Tashi Cell) in 2008, the market for mobile services has become more competitive, leading to improved services and possibly lower costs for the consumers (ADB, AAID, JICA, 2013) (MoIC, 2014). According to the Ministry of Information and Communication Annual Report 202098.5 percent of the places in the country have access to mobile networks and mobile subscribers which stands at 741,999. The percentage of the population (inclusive of floating population) availing mobile service stands at 99.1 percent. Specifically Internet coverage and Internet usage in Bhutan has increased significantly with total coverage of 97.4 per 100 inhabitants. As of December 2019, the total number of internet subscribers has reached 818,612 (MoIC, 2020). The total number of internet subscriptions includes 41,673 EDGE/GPRS subscriptions. In other words, 5.6 subscriptions per 100 inhabitants; 681,239 mobile broadband $(3 \mathrm{G}+4 \mathrm{G})$ subscriptions which is 90.96 subscriptions per 100 inhabitants; 3,386 fixed broadband subscriptions that is 0.5 subscriptions per 100 inhabitants and 3,435 lease line subscriptions that is 0.5 subscriptions per 100 inhabitants. This is undeniably an enormous increase in the user base of the country such as Bhutan (MoIC, 2020).

With such development in the ICT and telecommunication front leveraging the technology and its advancements becomes our individual role. Recalling the $112^{\text {th }}$ National Day address held on the 17 December 2019 at Changlimithang Stadium, His Majesty reminded the fellow Bhutanese citizens to maximize digitization to equal our neighboring countries such as India and China which are 


\section{International Journal of Engineering Applied Sciences and Technology, 2021 \\ Vol. 5, Issue 10, ISSN No. 2455-2143, Pages 66-73 \\ Published Online February 2021 in IJEAST (http://www.ijeast.com)}

exceptionally advanced and automated in the digital world (Daily Bhutan, 2019).

Having said that, MoIC, (2014) noted that Bhutan ranked $118^{\text {th }}$ out of 157 countries in terms of ICT development. Similarly, Bhutan ranked 22 out of 28 among the countries of the Asia and Pacific region. In other words, Bhutan has much to gain from the benefits of ICT development compared to other countries regionally and internationally (MoIC, 2014). As a matter of fact, ICT and technological advancement has a vital role to play in enhancing competitiveness, increasing productivity and economic development, and promoting greater social inclusion among many. It is indeed the foundation on which "An ICT enabled, Knowledge-Based Society as a Foundation for Gross National Happiness" will be built (MoIC, 2014).

Until recently Bhutan saw its importance, following the press release from the office of the prime minister on $27^{\text {th }}$ March 2019, all the agencies in the government and corporate sectors were asked to develop remote working guidelines and standard operating procedures (PMO, 2019). In other words, the works and service delivery were not to be disturbed; hence all the government corporate sectors had to immediately switch to virtual working environments such as virtual service delivery, virtual meetings, and virtual payments and so on. Similarly as per the press release from the Ministry of Education on August 11, all the schools and parents were asked to facilitate online learning provisions and online lessons via national television, YouTube and social media and so on (MoE, 2020). So the whole country's approach towards keeping the economy and educational institutes afloat was shifted to being virtual.

Hence, the internet and its connectivity and its strength to facilitate such major turnover were at question. Nonetheless, the services were delivered promptly reaching all the people in times of need. Having said that, the pandemic has shown no sign of recovery, and similar virtual engagements would keep continuing and if it so happens there are lots of spaces for further facilitation and improvements. Some of the major online systems for public service in the times of the pandemic are; Health Facility System, Druk Trace App, Quarantine Management System: Stay Home App, Control and Monitoring System, Check Post Management System, National and central COVID19 dashboard, Essential Goods Stockpiling system, Vegetable Market Information System, COVID19 middleware, and Essential Commodity Ordering System, Druk Gyalpo Relief Kidu System, Government to Citizen online system and many more (MoIC, 2020). These are all in collaboration with the relevant government stakeholders and private sectors to facilitate the government's response to the pandemic. In doing so, since this is an unprecedented approach and first of its kind there would have been many good things to learn from it or issues if any. Therefore, it is of paramount importance to understand the current services and its quality in the nick of time for learning and development purposes.

Therefore, taking lessons from the Royal Address on ICT and digitization as a note of precaution and considering its utmost role amidst the current pandemic situation, the study will try to access the service quality of the Bhutan Telecommunication Services in the country, particularly the internet service quality.

\section{OBJECTIVE}

The objective of this research is to assess the quality of services by understanding current internet services in the Country with further evaluation of factors and dimensions associated through the SERVQUAL instrument and provide relevant feedback and recommendations. The following are the hypotheses made prior to the study.

$\mathrm{H}_{0} 1$ : There is no statistically significant difference between perceived and expected overall service quality of internet services (RESPONSIVENESS, ASSURANCE, TANGIBILITY, EMPATHY, and RELIABILITY).

$\mathrm{H}_{1}$ 1: there is statistically a significant difference between perceived and expected overall service quality of internet services (RESPONSIVENESS, ASSURANCE, TANGIBILITY, EMPATHY, and RELIABILITY).

\section{LITERATURE REVIEW}

\subsection{The model of Service Quality Concept}

SERVQUAL is a multi-dimensional research instrument, which is designed to assess expectations and perceptions of a service (Waiba \& Chophel, 2019), (Yousapronpaiboon, 2014). It is based on expectancydisconfirmation paradigm, in which whether the consumers' expectation of the quality of service is confirmed or not by their actual perception of the service experience (Waiba \& Chophel, 2019), (Sabir et al., 2014).

The SERVQUAL instrument was first postulated in the 1980s by Parasuraman, Zeithaml and Berry, a team of three American researchers to measure quality in the service sector (Waiba \& Chophel, 2019), (Yousapronpaiboon, 2014). Soon in 1985, they worked on it and refined the model. It was a major breakthrough in assessment methods of service quality research (Waiba \& Chophel, 2019). The SERVQUAL model has been used in many retail and marketing studies and it has proved handy to assess quality of service in various aspects. To name few, it has proven to be good tool to study quality of education and academic systems (Pradela, 2015), (Yousapronpaiboon, 2014), it has 
also been used to study tourism and hospitality sectors (Stefano et al., 2015), (Pérez et al., 2011).

Moreover, the tool has also been widely used in bank, retail sectors and online business management approaches (Hizam \& Ahmed, 2019), (Siu \& Mou, 2005).

Therefore, considering the wide range of applicability of the model the study chose to carry out an empirical study based on the model and its dimensions.

\subsection{SERVQUAL Dimensions and Instruments}

Initially in the time of inception, there were ten dimensions which after further testing it was reduced from ten to five dimensions (Waiba \& Chophel, 2019), (Yousapronpaiboon, 2014), (Islam et al., 2014). According to Parasuraman, Zeithaml, and Berry, (1988), the five dimensions are identified as follows:

Table 1. Five dimensions of SERVQUAL model with number of items and definition.

\begin{tabular}{l|l|l} 
Dimension & $\begin{array}{l}\text { No. of } \\
\text { Items }\end{array}$ & Description \\
\hline Responsiveness & 4 & $\begin{array}{l}\text { the willingness to help } \\
\text { customers and provide } \\
\text { prompt service. }\end{array}$ \\
\hline Assurance & 3 & $\begin{array}{l}\text { the knowledge, courtesy of } \\
\text { employees and ability to } \\
\text { convey trust and confidence } \\
\text { in the customer towards the } \\
\text { service provider. }\end{array}$ \\
\hline Tangibles & 6 & $\begin{array}{l}\text { the appearance of physical } \\
\text { facilities, equipment, } \\
\text { personnel and } \\
\text { communication materials. }\end{array}$ \\
\hline Empathy & 4 & $\begin{array}{l}\text { the provision of caring, } \\
\text { individualized attention } \\
\text { provided to customers. }\end{array}$ \\
\hline the ability to perform the \\
promised service \\
dependably and accurately.
\end{tabular}

A total of 22 scale items were derived from these dimensions, and each item is measured on two responses; the customer expectations concerning a service (E) and the perception of the actual service delivered by the service sector (P) (Parasuraman et al., 1988).

\subsection{Model of Service Quality and Gap Theory}

In this method, service quality is the gap between perceived service and expected service, hence it is also known as gap theory (Pradela, 2015), (Muthupandian \& Vijayakumar, 2012). In the gap theory of service quality;

$$
\mathbf{Q}=\mathbf{P}-\mathbf{E}(\text { Quality }=\text { Perceptions }- \text { Expectations })
$$

Where a positive gap score would mean that expectations have been met or exceeded and service quality is perceived to be satisfied. Similarly, a negative gap score would mean that expectations have not been met and quality is unsatisfactory (Waiba \& Chophel, 2019), (Parasuraman et al., 1988).

Table 2. Examples of matched pairs of items in the SERVQUAL questionnaire.

\begin{tabular}{|c|c|c|}
\hline Dimension & $\begin{array}{l}\text { Eg. of } \\
\text { Expectation } \\
\text { Item }\end{array}$ & $\begin{array}{l}\text { Eg. of } \\
\text { Perception } \\
\text { Item }\end{array}$ \\
\hline Responsiveness & $\begin{array}{l}\text { Company should } \\
\text { provide timely } \\
\text { and efficient } \\
\text { service }\end{array}$ & $\begin{array}{l}\text { Company } \\
\text { provides timely } \\
\text { and efficient } \\
\text { service }\end{array}$ \\
\hline Assurance & $\begin{array}{l}\text { Company } \\
\text { employees should } \\
\text { be trustworthy }\end{array}$ & $\begin{array}{l}\text { Company } \\
\text { employees are } \\
\text { trustworthy }\end{array}$ \\
\hline Tangibles & $\begin{array}{l}\text { Company should } \\
\text { have adequate } \\
\text { resource and } \\
\text { technology }\end{array}$ & $\begin{array}{l}\text { Company has } \\
\text { adequate } \\
\text { resource and } \\
\text { technology }\end{array}$ \\
\hline Empathy & $\begin{array}{l}\text { Company should } \\
\text { always look after } \\
\text { the interests of } \\
\text { the customer }\end{array}$ & $\begin{array}{l}\text { Company } \\
\text { always looks } \\
\text { after the } \\
\text { interests of the } \\
\text { customer }\end{array}$ \\
\hline Reliability & $\begin{array}{l}\text { Company should } \\
\text { render services } \\
\text { as and when } \\
\text { required }\end{array}$ & $\begin{array}{l}\text { Company } \\
\text { renders services } \\
\text { as and when } \\
\text { required }\end{array}$ \\
\hline
\end{tabular}

Thus, the model of service quality or the gap theory conceptualized the SERVQUAL model. Gap scores can be analyzed for each individual statement and can be aggregated to give an overall gap score for each dimension (Waiba \& Chophel, 2019).

\subsection{Related Study}

There are many studies done on the assessment of internet service quality, in fact quality of telecom services in general. University of Kuala Lumpur also tried an assessment on the Internet of Things (IoT) and postulated a four dimension SERVQUAL extracted model which are privacy, functionality, efficiency and tangibility. However, the paper only presented possible models to assess IoT not exactly its service quality (Hizam \& Ahmed, 2019). Similarly, a case study in Hongkong on assessment of internet banking adopted the SERVQUAL model with slight modifications and came up with a four dimension model. The dimensions are credibility, efficiency, problem handling and security. The study noted that security was one important aspect to assessing e-services and its service quality perceptions. Having said that, even credibility and problem handling is said to have a significant impact on customer satisfaction. But more importantly, security and efficiency were significantly associated with future consumption behavior of the customers. Therefore, the 


\section{International Journal of Engineering Applied Sciences and Technology, 2021 \\ Vol. 5, Issue 10, ISSN No. 2455-2143, Pages 66-73 \\ Published Online February 2021 in IJEAST (http://www.ijeast.com)}

study considered security and efficiency in the items under the dimensions assurance and empathy accordingly (Siu \& Mou, 2005).

The SERVQUAL instrument allows to analyse the process and its elements helps to identify strong and weak points and not just the end results (Pradela, 2015). Further, Pradela, (2015) also noted that the model has been extensively used in assessing quality of education in many schools and academic institutes. Therefore, the study used SERVQUAL to assess the quality of internet service in the country.

In Bhutan too, the Department of Telecommunication and Technology (DITT), the Ministry of Information and Communication (MoIC) upon the instruction from the Prime Minister carried out an assessment to monitor the quality of internet in the country. The DITT sought data inputs collected by the dzongkhags. Although the approach was different but the purpose was the same, parameters such as testing internet speed using OpenSignal app, call dropping rate, call blocking rate, voice quality, SMS received/failure rate, signal failure and switchover were used to study. The study noted that overall voice quality for every dzongkhag was observed to be good in both the telecommunication network services (Tashi Cell and Bhutan Telecom). Having said that, in terms of internet download and upload speed it varied in different ways. While Samtse dzongkhag had observed the highest average downloads and uploads speed, Wangdue dzongkhag had observed the lowest average downloads and uploads speed with 4G TashiCell internet. On the contrary, Sarpang dzongkhag observed the highest average downloads speed and the lowest in Punakha with Bhutan Telecom 4G internet service (DITT, MoIC, 2018). Hence, the study in other words could be concluded that it had limitations and was deferring in every way since it was very technical in nature. Moreover, the study was undertaken by the presiding administrative body and not user or customer satisfaction based. Also, if the findings from all the parameters used were presented it would have given more clarity to the report but it was missing. Hence, this study was undertaken to supplement the study carried out by the DITT. Hence, looking at the past studies and scarce literature in Bhutanese context, the study will assess the internet service quality of the country in an open and customer satisfaction perspective using the model of Service Quality for learning and development purposes.

\section{METHODOLOGY}

\subsection{Questionnaire}

The study is based on quantitative analysis, it assessed the quality of internet services in the country provided by the relevant service providers. The data was collected through randomly distributed questionnaires through convenience sampling method via Google form survey.

The questionnaire was developed from the SERVQUAL model, in which there were three sections adopted with slight modification as per the given context from (Waiba \& Chophel, 2019) as follows;

Section A: General Profile to collect demographic details of the respondents such as gender, age, occupation, service provider.

Section B: Expectation of Service (same 22 items in five point likert-type scale of strongly agree, agree, neutral, disagree and strongly disagree were used).

Section C: Perception of Service (same 22 items in five point likert-type scale of strongly agree, agree, neutral, disagree and strongly disagree were used). Link to the questionnaire: https://forms.gle/cCjktUKpuobRoVYB7.

\subsection{Study Population and Sampling}

Sample size of 384 was determined using an online survey monkey tool taking total internet subscribers as the population size in the country at 818,612 , with marginal error at 5 percent and 95 percent confidence level.

\subsection{Data Analysis Methods-Statistical Planning}

The data for this study was analyzed using excel (Microsoft professional plus 2013) data analysis. The SERVQUAL score was calculated between perceived service and expected service with respect to the following measures: responsiveness, assurance, tangibles, empathy and reliability. Each dimension gap score was obtained by calculating the difference (means of responses) between the perceived (P) and expected (E) service scores $($ SERVQUAL score $=\mathrm{P}-\mathrm{E})$. The data was also analysed through paired two sample t-test to compare means and see the significant difference between expectation and perception of the services of each dimension item of all the five dimensions at hypothesized mean difference of zero, alpha value of 0.05 . Hence, if the p-value is less than the significance level, the difference between means is statistically significant.

General profile information was used to obtain basic data of the respondents and used as supportive figures in the discussion and finally SERVQUAL score was used for recommendation.

\section{FINDINGS AND DISCUSSION}

General Profile: the survey was responded by a total of 384 respondents of 818,612 population size, and the sample size was determined using survey monkey tool. Among the respondents 56 percent were male and 44 percent were female respondents. Most (66 percent) of the respondents were aged between 24-29 years of age. By occupation most respondents were government employees (33 percent) followed by private and corporate employees (26 percent). And most of the respondents of the study were Bhutan Telecom service subscribers ( 80 percent). The following table shows the overall demographic profile of the respondents.

Table 3. Demographic profile of the respondents. Demographic Profile $\quad$ Frequency/Percentage 


\begin{tabular}{|c|c|c|}
\hline Sample Populatio & & 818,612 \\
\hline Sample Size $(N)$ & & 384 \\
\hline & Male & 215 \\
\hline Genaer & Female & 169 \\
\hline & 13-18 Years & 4 \\
\hline & 19-23 Years & 61 \\
\hline Age & 24-29 Years & 252 \\
\hline & 30 Years Above & 67 \\
\hline & $\begin{array}{l}\text { Government } \\
\text { Employee }\end{array}$ & 126 \\
\hline Occupation & $\begin{array}{l}\text { Private/Corporate } \\
\text { Employee }\end{array}$ & 100 \\
\hline & Students & 44 \\
\hline & Unemployed & 83 \\
\hline & Others & 31 \\
\hline Internet Service & Bhutan Telecom & 309 \\
\hline Provider & Tashi Infocomm. & 75 \\
\hline
\end{tabular}

The study first looked at the overview of all the item expectation and perception scores and gap scores. Taking an average of all the 22 items and its gap scores it can be derived from the findings that the average gap score is at 0.6 which means that the expectations have not been met and quality of internet service is unsatisfactory (Waiba \& Chophel, 2019), (Parasuraman et al., 1988). In fact, all the 22 items are negative rated, meaning the internet service in the country is unsatisfactory based on the customer perception and expectation model. The following paragraphs will discuss the core areas that the ISPs have to focus and concentrate on and will also highlight the main areas that the customers' expect for improvements.

Considering individual items it was learnt that some of the high negative scores are for items; T_2, T_4, T_1 \& T_5 and following that T_3, T_6, E_1, E_3, E_4 \& Re_5. One of the core findings is that most of the high negative scores are for items related to TANGIBILITY, EMPATHY and RELIABILITY.

Table 4. Gap scores against each dimension.

\begin{tabular}{l|r|r|r} 
Items & $\begin{array}{l}\text { Perception } \\
\mathrm{P}\end{array}$ & $\begin{array}{l}\text { Expectation } \\
\text { E }\end{array}$ & \multicolumn{1}{c}{ Gap G } \\
\hline Responsiveness & 4.3 & 4.6 & -0.4 \\
\hline Assurance & 4.0 & 4.5 & -0.5 \\
\hline Tangibility & 3.8 & 4.6 & -0.8 \\
\hline Empathy & 3.9 & 4.6 & -0.6 \\
\hline Reliability & 4.0 & 4.5 & -0.5 \\
\hline Average & 4.0 & 4.6 & -0.6
\end{tabular}

In other words, the customers have high expectations for good and smooth infrastructure and connectivity lines, strong and without disturbances. In addition, it is also understood that customers feel there should be diverse and more options to data and internet package subscription.
Similarly, the customers also felt that their grievances and internet service issues could be better and promptly addressed with additional services such as more subcenters in clusters and populated settlement areas. The respondents felt that there could be a quota or student package at lower rates for them.

The study also considered looking at the mean scores of the customer perception and expectation of internet services to validate and confirm the null hypothesis. The null hypothesis was that there is no statistical significant difference between perceived and expected overall service quality of internet services but since the p-value is (twotail) is 0.003 which is lesser than the significance level at 0.05 the null hypothesis is rejected. The difference between the two means is statistically significant, and therefore there is a statistical significant difference between perceived and expected internet service quality.

Table 5. t-Test: Paired Two Sample for Means (Overall).

\begin{tabular}{l|l|l} 
& $\mathbf{P}$ & $\mathbf{E}$ \\
\hline & 4.257 & 4.630 \\
\hline Mean & 3.934 & 4.564 \\
\hline Variance & 0.010 & 0.002 \\
\hline Pearson Correlation & -0.993 & \\
\hline $\mathrm{df}$ & 3.000 & \\
\hline $\mathrm{t}$ Stat & -8.720 & \\
\hline $\mathrm{P}(\mathrm{T}<=\mathrm{t})$ one-tail & 0.002 & \\
\hline $\mathrm{t}$ Critical one-tail & 2.353 & \\
\hline
\end{tabular}

Table 6. Overview of all the item scores.

\begin{tabular}{|l|r|r|r|}
\hline $\begin{array}{l}\text { Item } \\
\text { Code }\end{array}$ & $\begin{array}{l}\text { Perception } \\
\text { P }\end{array}$ & $\begin{array}{l}\text { Expectation } \\
\text { E }\end{array}$ & \multicolumn{1}{l|}{ Gap G } \\
\hline Res_1 & 4.4 & 4.7 & -0.4 \\
\hline Res_2 & 4.1 & 4.4 & -0.3 \\
\hline Res_3 & 4.3 & 4.7 & -0.4 \\
\hline Res_4 & 4.3 & 4.7 & -0.5 \\
\hline A_1 & 4.2 & 4.7 & -0.5 \\
\hline A_2 & 3.8 & 4.4 & -0.6 \\
\hline A_3 & 4.1 & 4.5 & -0.5 \\
\hline T_1 & 3.8 & 4.7 & -0.8 \\
\hline T_2 & 3.7 & 4.7 & -1.0 \\
\hline T_3 & 3.8 & 4.5 & -0.7 \\
\hline T_4 & 3.7 & 4.7 & -1.0 \\
\hline T_5 & 3.9 & 4.7 & -0.8 \\
\hline T_6 & 3.9 & 4.5 & -0.7 \\
\hline E_1 & 3.9 & 4.7 & -0.7 \\
\hline E_2 & 4.0 & 4.4 & -0.5 \\
\hline E_3 & 3.9 & 4.6 & -0.7 \\
\hline E_4 & 3.9 & 4.5 & -0.7 \\
\hline Re_1 & 4.0 & 4.7 & -0.6 \\
\hline Re_2 & 4.0 & 4.2 & -0.2 \\
\hline Re_3 & 4.0 & 4.5 & -0.5 \\
\hline Re_4 & 4.0 & 4.6 & -0.6 \\
\hline Re_5 & 4.0 & 4.7 & -0.7 \\
\hline Avg. & 4.1 & 4.6 & -0.6 \\
\hline
\end{tabular}




\begin{tabular}{c|l|c}
\hline $\mathrm{P}(\mathrm{T}<=\mathrm{t})$ two-tail & 0.003 & $\begin{array}{c}\mathrm{SS} \\
(\mathrm{E}>\mathrm{P})\end{array}$ \\
\hline
\end{tabular}

On a lighter note, it was learnt that ASSURANCE and RESPONSIVENESS aspects such as safe payment and recharges; normal data cost and customer service quality and informing the customer on interruption of services; informing the customers on charges and usage updates and attending customer issues through the help desks has been scored average. Having said that, the gap scores are all negative and the ISPs should take it into consideration to improve their services on these fronts.

Paired two sample t-test was also done with all the five dimensions to see its statistical significance and to determine the highest and the lowest $\mathrm{p}$ value and to determine the difference of means between expected and perceived internet service quality. Among the five dimensions as mentioned in the earlier paragraph that the $\mathrm{p}$ value for ASSURANCE is statistically not significant. In other words, ASSURANCE aspects by the ISP is well taken care of and as discussed in the literature, assurance is one of the core dimensions that help retention and increased subscription by the customers.

On the other hand, the $\mathrm{p}$ value for the rest of the four dimensions are statistically significant which indicates that customer's expectation is higher than what they have actually perceived. Therefore, improvements can be made on the four dimensions. Of all an urgent consideration to improve on TANGIBILITY, EMPATHY and ASSURANCE is required to be focused by the ISPs.

Table 7. t-Test: Paired Two Sample for Means (Responsiveness).

\begin{tabular}{l|l|l}
\hline & $\mathbf{P}$ & $\mathbf{E}$ \\
\hline Mean & 4.362 & 4.714 \\
\hline Variance & 4.222 & 4.602 \\
\hline Pearson Correlation & 0.988 & \\
\hline df & 2.000 & \\
\hline t Stat & -6.050 & \\
\hline $\mathrm{P}(\mathrm{T}<=\mathrm{t})$ two-tail & 0.026 & $\begin{array}{c}\mathrm{SS} \\
(\mathrm{E}>\mathrm{P})\end{array}$
\end{tabular}

Table 8. t-Test: Paired Two Sample for Means (Assurance).

\begin{tabular}{l|l|l}
\hline & $\mathbf{P}$ & $\mathbf{E}$ \\
\hline & 4.667 & 4.167 \\
\hline Mean & 4.465 & 3.951 \\
\hline Variance & 0.011 & 0.031 \\
\hline Pearson Correlation & 1.000 & \\
\hline $\mathrm{df}$ & 1.000 & \\
\hline $\mathrm{t}$ Stat & 10.128 & \\
\hline $\mathrm{P}(\mathrm{T}<=\mathrm{t})$ two-tail & 0.063 & $\begin{array}{c}\mathrm{SNS} \\
(\mathrm{E}=\mathrm{P})\end{array}$
\end{tabular}

Table 9. t-Test: Paired Two Sample for Means (Tangibility).

\begin{tabular}{l|l|l}
\hline & $\mathbf{P}$ & $\mathbf{E}$ \\
\hline & 4.669 & 3.846 \\
\hline Mean & 4.616 & 3.786 \\
\hline Variance & 0.008 & 0.006 \\
\hline $\begin{array}{l}\text { Pearson } \\
\text { Correlation }\end{array}$ & -0.677 & \\
\hline $\mathrm{df}$ & 4.000 & \\
\hline $\mathrm{t}$ Stat & 12.143 & \\
\hline $\mathrm{P}(\mathrm{T}<=\mathrm{t})$ two-tail & 0.000 & $\begin{array}{c}\mathrm{SS} \\
(\mathrm{E}>\mathrm{P})\end{array}$
\end{tabular}

Table 10. t-Test: Paired Two Sample for Means (Empathy).

\begin{tabular}{l|l|l}
\hline & $\mathbf{P}$ & $\mathbf{E}$ \\
\hline & 4.6641 & 3.9375 \\
\hline Mean & 4.5321 & 3.9123 \\
\hline Variance & 0.0059 & 0.0020 \\
\hline $\begin{array}{l}\text { Pearson } \\
\text { Correlation }\end{array}$ & -0.7760 & \\
\hline Df & 2.0000 & \\
\hline t Stat & 9.3042 & \\
\hline $\mathrm{P}(\mathrm{T}<=\mathrm{t})$ two-tail & 0.0114 & $\mathrm{SS}(\mathrm{E}>\mathrm{P})$
\end{tabular}

Table 11. t-Test: Paired Two Sample for Means (Reliability).

\begin{tabular}{l|l|l} 
for Means (Reliability). & \\
\hline & $\mathbf{P}$ & $\mathbf{E}$ \\
\hline & 4.659 & 4.021 \\
\hline Mean & 4.503 & 3.991 \\
\hline Variance & 0.061 & 0.000 \\
\hline $\begin{array}{l}\text { Pearson } \\
\text { Correlation }\end{array}$ & 0.253 & \\
\hline df & 3.000 & \\
\hline t Stat & 4.181 & \\
\hline $\mathrm{P}(\mathrm{T}<=\mathrm{t})$ two-tail & 0.025 & SS (E>P)
\end{tabular}


Table 12. All the item average score by Occupation.

\begin{tabular}{l|r|r|l}
\hline Occupation & $\begin{array}{l}\text { Perception } \\
\text { P }\end{array}$ & $\begin{array}{l}\text { Expectation } \\
\text { E }\end{array}$ & $\begin{array}{l}\text { Gap } \\
\text { G }\end{array}$ \\
\hline $\begin{array}{l}\text { Government } \\
\text { Employee }\end{array}$ & 4.0 & 4.6 & -0.6 \\
\hline $\begin{array}{l}\text { Private/Corporate } \\
\text { Employee }\end{array}$ & 4.0 & 4.6 & -0.6 \\
\hline Students & 4.0 & 4.5 & -0.5 \\
\hline $\begin{array}{l}\text { Unemployed \& } \\
\text { Others }\end{array}$ & 3.9 & 4.6 & -0.7 \\
\hline Average & 4.0 & 4.6 & -0.6
\end{tabular}

The study also chose to cross tabulate and look at the gap score by occupation and ISP. It was interesting to observe that the highest negative score was noted in unemployed and other individuals, this can be attributed to the fact that they use cellular internet data and due to increasing users the speed and quality deteriorates. On the other hand, it is noteworthy that given the network connectivity and internet connections in Government and Private/Corporate offices such as broadband, working online could be better comparatively. Over all, irrespective of the type of occupation the internet service is observed to be unsatisfactory in general.

Similarly, the gap score by the ISP was also assessed. It was observed that there is not much difference in the quality of services provided between Bhutan Telecom and Tashi Cell. The mean difference is 0.097 and it is statistically not significant.

Table 13. All the item average score by ISP.

\begin{tabular}{l|r|r|l}
\hline $\begin{array}{l}\text { Internet Service } \\
\text { Provider }\end{array}$ & $\begin{array}{l}\text { Perception } \\
\text { P }\end{array}$ & $\begin{array}{l}\text { Expectation } \\
\text { E }\end{array}$ & $\begin{array}{l}\text { Gap } \\
\text { G }\end{array}$ \\
\hline $\begin{array}{l}\text { Bhutan Telecom } \\
\text { (BT) }\end{array}$ & 4.0 & 4.6 & -0.6 \\
\hline $\begin{array}{l}\text { Tashi InfoComm. } \\
\text { (Tcell) }\end{array}$ & 3.9 & 4.4 & -0.5 \\
\hline Average & 4.0 & 4.5 & -0.6
\end{tabular}

\section{CONFLICT OF INTEREST}

The authors declare that there exists no conflict of interest among the authors and for publication and dissemination

\section{REFERENCE}

[1] Daily Bhutan. (2019, December 19). Historical 112th National Day. Daily Bhutan. https://dailybhutan.com/article/historical-112th-nationalday

[2] DITT, MoIC. (2018). Mobile Internet Connectivity Report. Department of Telecommunication and Technology, Ministry of Information and Communication.

https://www.dit.gov.bt/sites/default/files/Internet\%20Con
nectivity\%20Report\%20\%28July\%20September\%2C2018\%29.pdf

[3] Hizam, S. M., \& Ahmed, W. (2019). A Conceptual Paper on SERVQUAL-Framework for Assessing Quality of Internet of Things (IoT) Services. International Journal of Financial Research, 10(5). :10.5430/ijfr.v10n5p387

[4] Islam, R., Chowdhury, M. S., Sarker, M. S., \& Ahmed, S. (2014). MEASURING CUSTOMER'S SATISFACTION ON BUS TRANSPORTATION. American Journal of Economics and Business Administration, 6(1), 34-41. 10.3844/ajebasp.2014.34.41

[5] MoE. (2020, August 11). Notification from Ministry of Education on lockdown. Ministry of Education. http://www.education.gov.bt/wp-

content/uploads/2020/08/Royal-Government-ofBhutan.pdf

[6] MoIC. (2014). Bhutan Telecommunications and Broadband Policy. Ministry of Information and Communication,. $\quad$ https://www.gnhc.gov.bt/en/wpcontent/uploads/2017/05/Bhutan-Telecommunicationsand-Broadband-Policy-V2.4.pdf

[7] MoIC. (2020). Annual Info-Comm and Transport Statistical Bulletin. In Annual Info-Comm and Transport Statistical Bulletin 2020 (11th ed., pp. 1-58). Ministry of Information and Communication, Policy and Planning Division. https://www.moic.gov.bt/wpcontent/uploads/2020/02/2020-Annual-Info-Comm-andTransport-Statistical-Bulletin-2019.pdf

[8] MoIC. (2020, December 01). ANNUAL REPORT: (JULY 2019-JUNE 2020). Ministry of Information and Communication. https://www.moic.gov.bt/wpcontent/uploads/2021/01/Annual_Report_2020.pdf

[9] Muthupandian, K. S., \& Vijayakumar, C. (2012, January 12). Measurement of passengers service quality in public transportation: servqual analysis. Munich Personal RePEc Archive, MPRA Paper No. 38584, posted 5. May $2012 \quad$ 14:43 UTC. https://mpra.ub.unimuenchen.de/38584/

[10] Parasuraman, A., Zeithaml, V. A., \& Berry, L. L. (1988, Spring). SERVQUAL: A Multiple-Item Scale for Measuring Consumer Perceptions of Service Quality. Journal of Retailing, 64(1).

[11] Pérez, F. M. D., Moreno, M. C. M., \& Cejas, M. Y. B. (2011). The User Gap (Perceptions-Expectations) in Tourism Accommodation Services in Mérida State, Venezuela. Forum Empresaria, 16(1), 22-57. ISSN: 15418561

[12] PMO. (2019, March 27). Measures for highest level of prevention. Office of the Prime Minister of Bhutan. https://www.pmo.gov.bt/press-release-measures-forhighest-level-of-prevention/

[13] Pradela, A. (2015). Quality of graduates' preparation for labour market - a ServQual analysis. Procedia - Social and Behavioral Sciences, 174 ( 2015 ) 1671 - 1677. 10.1016/j.sbspro.2015.01.820

[14] Sabir, R. I., Javed, S., Ahmad, W., Noor, N., \& Munir, H. M. (2014). Assessing Customer Satisfaction 
Level of Transport Services Using Servqual: A Case OF Daewoo Express, Pakistan. Journal of Basic and Applied Scientific Research, 4(2), 207-213. ISSN 2090-4304

[15] Siu, N. Y.-M., \& Mou, J. C.-W. (2005, August). Measuring Service Quality in Internet Banking: The Case of Hong Kong. Journal of International Consumer Marketing, 17(4). 10.1300/J046v17n04_06

[16] Stefano, Filho, C., Barichello, \& Sohn. (2015). A fuzzy SERVQUAL based method for evaluated of service quality in the hotel industry. Procedia CIRP, 30, 433-438. 10.1016/j.procir.2015.02.140

[17] Waiba, P. S., \& Chophel, T. (2019, Spring). Efficacy of City Bus Service in Thimphu Thromde; Service and Service Need Assessment. Bhutan Journal of Research and Development, 8(1), 34-46. ISSN-1321-8545 [18] Yousapronpaiboon, K. (2014). SERVQUAL: Measuring higher education service quality in Thailand. Procedia - Social and Behavioral Sciences, (116), 10881095. 10.1016/j.sbspro.2014.01.350 